\title{
IMPLANTED MUSCLE DERIVED STEM CELLS AMELIORATE ERECTILE DYSFUNCTION IN A RAT MODEL OF TYPE 2 DIABETES, BUT THEIR REPAIR CAPACITY IS IMPAIRED BY THEIR PRIOR EXPOSURE TO THE DIABETIC MILIEU
}

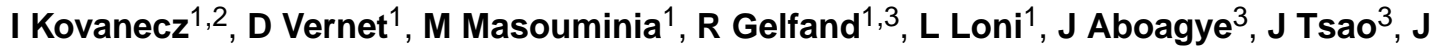 \\ Rajfer $^{1,2}$, and NF Gonzalez-Cadavid ${ }^{1,2,3}$ \\ ${ }^{1}$ Division of Urology, Department of Surgery, Harbor-UCLA Medical Center and Los Angeles \\ Biomedical Research Institute, Torrance, CA \\ 2Department of Urology, David Geffen School of Medicine at UCLA, Los Angeles, CA \\ ${ }^{3}$ Department of Medicine, Charles Drew University of Medicine and Science, Los Angeles, CA
}

\begin{abstract}
Introduction-Muscle derived stem cells (MDSC) and other stem cells implanted into the penile corpora cavernosa ameliorate erectile dysfunction in type 1 diabetic (T1D) rat models by replenishing the lost corporal smooth muscle cells (SMC) and reducing fibrosis. However, no conclusive data on this question in T2/D/obesity models is available. Aim. We studied whether: a) MDSC from T2D Obese Zucker (OZ) rats at an early stage of diabetes (ED-SC), counteract corporal veno-occlusive dysfunction (CVOD) and corporal SMC loss/lipofibrosis when implanted in the $\mathrm{OZ}$ rats at a late stage of diabetes; b) MDSC from these late diabetes OZ rats (LD-SC) differ from ED-SC in their gene transcriptional phenotype and repair capacity.
\end{abstract}

Methods and Outcomes-ED-SC and LD-SC were compared by DNA microarray assays, and ED-SC were incubated in vitro under high glucose conditions (ED-HG-SC). These three MDSC types were injected into the corpora cavernosa of late diabetes $\mathrm{OZ}$ rats $(\mathbf{O Z} / \mathbf{E D}, \mathbf{O Z} / \mathbf{L D}$, and OZ/ED-HG rats respectively). Untreated OZ (OZ/UT) and non-diabetic Lean Zucker (LZ/UT) rats were controls. Two months later, rats were subjected to cavernosometry and the penile shaft and corporal tissues were subjected to histopathology and DNA microarray assays.

Results-Implanted ED-SC and ED-HG-SC, improved CVOD, counteracted corporal SMC/ collagen decrease and fat infiltration in long-term T2D rats, and upregulated nNOS and eNOS. LD-SC acquired an inflammatory/profibrotic/oxidative/dyslipidemic transcriptional phenotype, and failed to repair the corporal tissue.

\footnotetext{
\#Corresponding author: Nestor F. Gonzalez-Cadavid, Ph.D., LABioMed at Harbor-UCLA Medical Center, Urology Research Laboratory, Building C3, 1124 West Carson Street, Torrance, CA, 90502, Telephone: 310-222-3824; fax: 310-222-1914; ; Email: ncadavid@ucla.edu

Publisher's Disclaimer: This is a PDF file of an unedited manuscript that has been accepted for publication. As a service to our customers we are providing this early version of the manuscript. The manuscript will undergo copyediting, typesetting, and review of the resulting proof before it is published in its final citable form. Please note that during the production process errors may be discovered which could affect the content, and all legal disclaimers that apply to the journal pertain.
} 
Conclusions-MDSC from pre-diabetic rats injected into the corpora cavernosa of long-term diabetic T2D rats improve CVOD and the underlying histopathology. In contrast, MDSC from long-term uncontrolled diabetic T2D rats, are imprinted by the hyperglycemic/dyslipidemic milieu with a noxious phenotype associated with an impaired tissue repair capacity. Diabetes-impacted stem cells may lack tissue repair efficacy as autografts, and should either be reprogrammed in vitro, or substituted by stem cells from allogenic non-diabetic sources.

\section{Keywords}

corpora cavernosa; corporal veno-occlusive dysfunction; diabetes; dyslipidemia; fibrosis; hyperglycemia; myostatin; obesity; smooth muscle; stem cell damage

\section{INTRODUCTION}

Erectile dysfunction is a major complication of type 2 diabetes (T2D), afflicting over 60$75 \%$ of diabetic patients $\left({ }^{1},{ }^{2}\right)$. It impairs the quality of life of patients and their partners and leads to considerable health costs $\left({ }^{3},{ }^{4}\right)$. Erectile dysfunction is also prevalent in obese and metabolic syndrome patients $\left({ }^{5}{ }^{7}\right)$. The risk factors and the histopathology that underlie erectile dysfunction are very similar to those affecting the media smooth muscle in the arterial tree in arteriosclerosis and hypertension $\left({ }^{8},{ }^{9}\right)$. Over $40 \%$ of T2D patients with erectile dysfunction are refractory to palliative treatment with oral PDE5 inhibitors taken to induce an erection $(10,11)$, and there are no convincing evidence that improving glycemic control/lifestyle alone reverses erectile dysfunction $\left(12 \_14\right)$. Therefore, new therapies for long-term correction of the underlying histopathology of the penile corpora cavernosa are needed to ameliorate erectile dysfunction.

The prevalent form of erectile dysfunction in T2D is vasculogenic, presenting mostly as corporal veno-occlusive dysfunction (CVOD) $\left({ }^{15}, 16\right)$, the loss of compliance of the corporal smooth muscle to relax and compress the veins against the rigid tunica albuginea to retain the blood during an erection. CVOD is essentially a corporal smooth muscle cell (SMC) dysfunction caused by SMC loss or damage, compounded by endothelial damage and fibrosis $\left({ }^{17}\right)$.

A novel therapy to repair the penile corporal damage and CVOD induced by T2D is based on the corporal implantation of adult stem cells that can differentiate into SMC and other cell lineages impaired by the diabetic milieu. Most experimental studies of erectile dysfunction in diabetes have been conducted in streptozotocin-induced T1D in rats and mice $\left({ }^{18}\right)$, but they do not reflect the impact of obesity and dyslipidemia occurring in T2D, and streptozotocin is a toxic agent that damages the pancreas and induces hypoinsulinemia. The reports show amelioration of erectile dysfunction with adipose derived, stromal vascular, bone marrow mesenchymal, and endothelial progenitor stem cells, either native or modified by gene transfer $\left({ }^{19}\right)$.

There is a paucity of studies on rodent models of T2D, metabolic syndrome, or obesity, like in the obese Zucker $(\mathbf{O Z})$ rat, that starting at around 4 months of age is considered initially as a model of metabolic syndrome, showing insulin resistance, borderline hyperglycemia, and mild dyslipidemia and overweight, but that at about 6-7 months of age evolves like in 
humans into a model of frank T2D with moderate hyperglycemia, hyperinsulinemia, high HbA1C, morbid obesity, and severe dyslipidemia, accompanied by nephropathy and arterial media fibrosis (19_23). Stem cell therapy of erectile dysfunction in T2D is limited to a report on rat adipose derived stem cells, that however was done in a streptozotocin-induced rats and the other is questionable in terms of the origin of the corporal damage corrected by the stem cells (see discussion) $\left({ }^{24}, 25\right)$. In humans, there is a report of a transient regain of morning erections and response to PDE5 inhibitors in seven diabetic patients that were awaiting penile prostheses, but before one year all returned to unresponsive erectile dysfunction $\left({ }^{26}\right)$..

Muscle derived stem cells (MDSC) are promising because of the easy access to biopsies and their capacity to differentiate into angiogenic, neural, and other lineages $\left(27 \_30\right)$, under paracrine and juxtacrine cues from the host tissue. Our group applied them as therapy for erectile dysfunction $\left({ }^{31}, 32\right)$ and for other conditions $\left(33 \_35\right)$, but they have not been tested in T2D. A major obstacle for their clinical translation, as well as for stem cells in general, is that if they are used as autologous implants from the same patient they would have been subjected in the muscle to the same T2D milieu that in the corpora cavernosa damages the SMC and other differentiated cells. Although allergenic implants of stem cells from nondiabetic subjects may overcome this problem, immunorejection risks have to be controlled.

The purpose of this study was to investigate the hypotheses that: a) intra-corporal implantation of MDSC counteracts corporal loss of SMC, lipofibrosis and CVOD in the OZ rat, b) the tissue repair capacity of MDSC isolated from long-term diabetes T2D donors is impaired by their exposure to the diabetic milieu, and c) this is associated with alterations of their global transcriptional gene expression signature in markers of inflammation, fibrosis, dyslipidemia, and other noxious changes, that clinically may reduce the effectiveness of autografts in T2D patients

\section{METHODS AND MAIN OUTCOME MEASURES}

\section{Animals and MDSC isolation}

Animals were used and treated according to the 'Principles of laboratory animal care' (The National Institutes of Health) with an Institutional Animal Care and Use Committeeapproved protocol. Male obese Zucker fa/fa rats $(\mathbf{O Z})$ were used at 3 months of age, when they are only mildly hyperglycemic and slightly overweight, as compared to their lean nondiabetic counterpart rats (LZ) ${ }^{20 \_23}$ ). Allergenic MDSC were isolated and named "earlydiabetic stem cells" (ED-SC) because they were not exposed long-term to the considerable hyperglycemic and dyslipidemic milieu of frankly diabetic aged OZ rats. Another set of MDSC was isolated from these older OZ counterparts (7 months old), already severely obese and dyslipidemic but with only a moderately higher glycemia (see results). These MDSC, in contrast to the ED-SC, were exposed for about 4 additional months to the more intense and prolonged T2D milieu, and named "late-diabetic stem cells" (LD-SC).

MDSC were isolated from the hind limb muscles from the two OZ rat groups ( $\mathrm{n}=2 /$ group), using the preplating procedure, a validated method for MDSC isolation, as in our previous reports for mice and Fisher 344 rats $\left(31 \_35\right.$ ). Preplate fraction 6 (pP6) is the cell population 
containing MDSCs, that was subjected to Sca 1 selection and flow cytometry as described. Low $(5.6 \mathrm{mM})$ or high $(22.2 \mathrm{mM})$ glucose were used for ED-SC and LD-SC maintenance, respectively. To determine the effect of high glucose on the ED-SC, they were incubated for 1 week in the $22.2 \mathrm{mM}$ medium and named early-diabetic high glucose stem cells (ED-HGSC)

\section{Animal procedures}

$\mathrm{OZ}$ rats at 7 months of age were divided in four groups ( $\mathrm{n}=8 /$ group) that were then named as follows: 1) OZ/UT: receiving only intracorporal saline injection (untreated); 2) OZ/ED: receiving intracorporal injection of ED-LZ $\left(10^{6}\right.$ cells); 3) OZ/ED-HG: as group \#2 but injected with ED-HG-SC; and 4) OZ/LD: as group \#2 but injected with LD-SC. An additional group, 5) LZ/UT comprised untreated LZ rats. Groups 2-4 were re-injected at 5 weeks with the respective MDSC types $\left(10^{6}\right.$ cells) or vehicle, in order for the freshly implanted cells to compensate for the putative damage of the initially implanted cells by the T2D milieu in the corpora cavernosa.

Eight weeks after the first implantation, cavernosometry was performed under pentothal anesthesia $\left({ }^{20}\right)$, to determine: a) basal intracavernosal pressure (ICP) and ICP after papaverine administration and b) 'drop rate' by recording the fall in ICP from $100 \mathrm{mmHg}$ within 1 min after the infusion was stopped.

Immediately before cavernosometry, body weights were determined, and blood was extracted from the tail and glucose levels were determined using a blood glucose meter (Accu-Chek Active, Roche, Ireland). At sacrifice, the penises were excised, denuded, and the penile shaft dissected. Small portions of shaft tissue were fixed overnight in $10 \%$ formalin, washed in PBS and stored at $4{ }^{\circ} \mathrm{C}$ in $70 \%$ ethanol. The remainde $\mathrm{r}$ of shaft tissue (not fixed) was either used for OCT embedding or directly frozen in liquid nitrogen and stored at $-80{ }^{\circ} \mathrm{C}$.

\section{Quantitative histochemistry}

Tissue sections $(6-8 \mu \mathrm{m})$ were obtained from paraffin-wax embedded penile shaft tissue, and adjacent tissue sections were used for Masson trichrome staining $\left(20 \_23,36\right.$ ) for collagen (blue) and SM cells (red). The OCT aliquots of the penile shaft were used for obtaining frozen tissue sections that were subjected to Oil Red O staining for detecting fat droplets $\left.{ }^{36}\right)$. Quantitative image analysis (QIA) was performed by computerized densitometry $(20$ 23,36 ). $40 \times$ magnification pictures ( $4 \times$ objective/10X eyepiece) were taken comprising the whole cross section of the penile shaft. For all determinations, only the corpora cavernosa were analyzed in a computerized grid and expressed as \% of positive area vs. total area. At least 3 matched sections per animal and 8 animals per group were analyzed.

\section{Quantitative western blots}

Penile tissue homogenates were subjected to western blot analysis as described $(20$ $23,36,39$ ). The primary antibodies used were as follows: a) calponin 1 (Calp 1) mouse monoclonal (Santa Cruz Biotechnology, Inc. Santa Cruz, CA); b) a-smooth muscle actin (ASMA), mouse monoclonal (Sigma/Aldrich St Louis, MO); c) nNOS rabbit monoclonal 
(Abcam, Cambridge Ms); d) eNOS, polyclonal (Enzo Life Sciences, Farmingdale, NY), 1/1000; myostatin (GDF8); e) beta actin, monoclonal as housekeeping protein (Santa Cruz Biotechnology, Santa Cruz, California). Densitometric analysis was performed correcting by the housekeeping proteins.

\section{Collagen Content}

Collagen was estimated in samples of fresh denuded penile shaft tissue homogenates in saline as described $(23,37$ ) by the hydroxyproline procedure. Values were expressed as $\mu \mathrm{g}$ of collagen per mg of tissue.

\section{Global transcriptional profile (signature)}

For the multiple mRNA profile, RNA from cultures from the ED-SC and LD-SC, was purified using the RNeasy Plus Micro kit (Qiagen), with RNA quality determined by the Agilent 2100 Bioanalyzer. Assays $(36,38$ ) were performed on a duplicate set of penile tissue RNAs by the UCLA DNA microarray core, applying the Affymetrix Rat Gene array for 29,215 sequences, that yields the baseline gene expression as an arbitrary value for each gene, obtained with several sequence region probes, an internal compensation in multiple spots, and automatic normalization against multiple housekeeping genes,. Only genes that were up- or down-regulated by at least 2-fold were considered unless specifically detailed. The impact of the T2D milieu on the LD-SC was expressed as the ratios between the LD-SC values for each selected gene and the respective control ED-SC values. These sequence data have been submitted to the DDBJ/EMBL/GenBank databases under accession number in process.

\section{Statistical analysis}

Values are expressed as the mean \pm SEM. The normality distribution of the data was established using the Wilk-Shapiro test. Multiple comparisons were analyzed by single factor ANOVA, followed by post hoc comparisons with the Tukey test. Differences among groups were considered statistically significant at $P<0.05$.

\section{RESULTS}

The MDSC are subjected in vivo to milieus of various levels of hyperglycemia, insulinemia, and dyslipidemia according to whether they are isolated from short term early T2D or longterm late T2D, prior to their intracorporal implantation to treat erectile dysfunction

The 7 month old OZ rats (as compared to the same age LZ rats) had frank T2D as indicated by a mean non-fasting glycemia of 320 for $\mathrm{OZ}$ vs $110 \mathrm{mg} / \mathrm{dl}$ for age matched LZ. At completion, the 9 month old OZ rats displayed a milder non-fasting hyperglycemia which was still much higher than for the LZ rats of the same age (202+/-8 vs $104+/-4 \mathrm{mg} / \mathrm{dl}$, respectively). The same pattern was seen for body weight, indicating a severe obesity (745+l -26 vs $494+/-15 \mathrm{~g})$. MDSC treatment did not induce any significant change in either glycemia or body weight.

According to the data from Charles River on our batch of rats, the 7 month old OZ rats used for the LD-SC isolation were, in comparison to the 3 months old rats used for the ED-SC 
isolation, or the 3 month old LZ rats as controls, respectively, severely hyper-insulinemic (non-fasting 25,000 vs. 6,500 vs. data not available, pg/ml), and hyper-cholesterolemic (420 vs. 150 vs. $100 \mathrm{mg} / \mathrm{dl}$ ), and had very high triacylglycerides (1,650 vs. 700 vs. $100 \mathrm{mg} / \mathrm{dl}$ ). This indicates that the LD-SC had been exposed for a long time to an increasingly hyperinsulinemic and dyslipidemic milieu, whereas the ED-SC were exposed for a shorter period (4 months less) to a virtually normoinsulinemic and only slightly hyperlipidemic milieu. The differences in glycemia were less striking (non-fasting 200-250 for LD-SC exposure vs. 150-100 for ED-SC exposure and 100-120 mg/dl for the LZ exposure). No non-diabetic MDSC were isolated and tested, since this would require a different nonallogeneic strain as a source, the LZ rats, thus complicating the comparison and also the statistics and the study itself if a sixth experimental group would have been added. So, the ED-SC was taken as a control, considering that in addition, the non-diabetic MDSC have already been shown by us to ameliorate corporal SMC loss and fibrosis and CVOD in non diabetic rats $(31,32,47)$.

\section{The long-term exposure to this T2D milieu causes alterations in the global transcriptional expression signature of MDSC for pathways that may affect their tissue repair capacity}

RNA was isolated from LD-SC and ED-SC representing respectively the MDSC isolated from the skeletal muscle of the late and early diabetic rats, and subjected to DNA microarray analysis. About 3\% of the DNA sequences (of which many were not known genes) were upregulated and $1.5 \%$ were down-regulated by factors of $>2.0$ in LD-SC as compared to EDSC, thus keeping the remaining $95.5 \%$ sequences that were not different by these criteria as conclusive proof of the essential reproducibility of our results. The transcription of genes related to selected noxious pathways were modified in the LD-SC as compared to ED-SC (Table 1). For instance, some mRNAs related to inflammation were upregulated by a factor as high as 68, particularly IL1 that was expressed at very low levels in ED-SC and remarkably increased in LD-SC, as well as prostaglandin E synthetase and prostaglandin and prostacyclin receptors.

Genes related to fibrosis and SMC loss or contraction, like Edmrb, MMP9, Smad 6 and 9, TGF $\beta 1$, or myostatin were upregulated from 25 - to a modest 1.5 -fold, whereas others belonging to an opposite defense mechanism against fibrosis and smooth muscle cell loss, like FGF7 (also named KGF), follistatin (myostatin binding and inactivation), Smad 7 (against Smad 3 and 4), decorin (against TGFß1 and myostatin), were upregulated from 24fold to 1.7 -fold. Similarly, in the oxidative stress-related genes, xanthine dehydrogenase (Xdh), as an oxidative enzyme, and superoxide dismutase (Sod3), for an antioxidant enzyme, varied from 5.1- to 4.5-fold.

The imprint of MDSC by the diabetic milieu was also evident on genes related to other important pathways (Table 2). For instance, the downregulation of markers of differentiated striated muscle cells, such as myosin heavy chain by a factor of 20 -fold. Conversely, several members of the $\mathrm{CD}$ surface marker antigens were upregulated within a range varying between 13 and 2.3-fold, such as CD24 or CD93. The CDs provide targets for immunophenotyping by acting as receptors or ligands that trigger cell signaling or are involved in cell adhesion in processes as diverse as inflammation, adaptive immunity, 
autoimmune diseases and cancer, There are some CDs that were downregulated by a factor of 3.0, such as CD34, precisely a marker of MDSC. Many diabetes-related chemokines were upregulated by 21- to 5.4-fold, among them $\mathrm{CxCl1}$ and $\mathrm{CC} 17$, and the expression of dyslipidemic markers was also altered.

The considerable magnitude of the selected changes and their internal consistency of multiple genes within functional gene families related to the multiple biological impact on the expected targets of stem cell damage, made unnecessary at this point the RT/PCR validation. In this case, it may turn to be arbitrary if only certain genes are selected among the scores reported in the tables, but would be of interest for future studies of specific genes.

\section{The ED-SC, and to a lesser extent the ED-HG-SC, improved erectile function and corporal SMC/collagen and reduced collagen, when injected into the corpora cavernosa of late diabetes $\mathrm{OZ}$ rats, but the LD-SC failed to exert these beneficial effects}

The long-term ( 7 month old) diabetic OZ rats were either left untreated or injected twice intracorporally with the three types of MDSC for 2 months. The determination of erectile function by cavernosometry showed that the OZ/UT rats had CVOD, denoted by the reduction of the papaverine response and the increase of the drop rate as compared to the LZ/UT rats (Fig. 1). The papaverine response was corrected in the OZ/ED rats but not in the OZ/LD rats, in comparison to the OZ/UT and LZ/UT rats, thus supporting the assumption that the OZ-ED were effective in ameliorating erectile dysfunction in T2D rats but that the long-term exposure of the MDSC to the T2D milieu in the LD-SC had impaired their corporal tissue repair ability (Fig. 1). The short-term incubation (1 week) of the ED-SC with high glucose slightly reduced, but not significantly the ICP after papaverine, due to a variable response of the individual animals within the OZ/ED-HG group. The increased drop rate was not significantly modified by any treatment.

The effects on the papaverine response were reflected in the expected changes in the relative SMC/collagen content in the corpora cavernosa, a standard way of measuring the corporal tissue composition, as determined by quantitative histochemical determination restricted to the corpora cavernosa, i.e., excluding the tunica albuginea and the corpus spongiosum (Fig. 2 top). The SMC/collagen ratio was decreased in the OZ/UT as compared to the LZ/UT and normalized in the OZ/ED but not in the OZ/LD, with again no significant difference in the OZ/ED-HG as compared to the OZ/ED. In turn Fig. 2 bottom shows collagen content in the penile shaft tissue homogenate measured by the hydroxyproline assay, that is increased in the OZ/UT control as compared to the LZ/UT. Treatment of the OZ rats with MDSC led to a reduction in the control value in the OZ/ED but not in the OZ/LD rats. Altogether, this showed that the corporal fibrosis and CVOD caused by T2D was partially compensated by the ED-SC but not by the LD-SC, possibly due to the impairment in the MDSC caused by the long-term exposure of the stem cells to a diabetic milieu. 
The ED-SC and ED-HG-SC improved the myofibroblast/SMC content when injected into the corpora cavernosa of late diabetes $\mathrm{OZ}$ rats, but the LD-SC failed to exert these beneficial effects and induced myostatin expression and fat infiltration

The western blot analysis of denuded penile shaft tissue of the corporal ratio between the protein levels of calponin, as marker of SMC only, and ASMA, as a marker of myofibroblasts and SMC, indicated that the OZ/ED, but not the OZ/LD, had a much higher ratio than the OZ/UT and even the LZ/UT, with an intermediate value for the OZ/LD-HG (Fig. 3 left). This indicates that the SMC/myofibroblast balance is increased by the ED-SC but not by the LD-SC.

In previous work we reported the presence and expression in the SMC of corpora cavernosa and corpus spongiosum, of a TGF $\beta$ family protein, myostatin $\left({ }^{39}\right)$, that increased after MDSC implantation in the corpora cavernosa of rats with CVOD caused by cavernosal nerve damage. We also observed myostatin in the fibroblasts and myofibroblasts of the tunica albuginea. Myostatin is the main inhibitor of skeletal muscle mass and a profibrotic effector ${ }^{40}$ ), and we assume that may play a similar role in the smooth muscle, and therefore interfere with MDSC action $\left({ }^{39}\right)$. Fig. 3 right shows that neither T2D per se (OZ/UT vs. LZ/UT rats), nor intracorporal implantation of ED-SC or ED-HG-SC increase the levels of the 25 and $50 \mathrm{KDa}$ forms of the cleaved active myostatin protein and its precursor. However, there was a significant increase observed in the $25 \mathrm{kDa}$ form of myostatin induced by the treatment of OZ rats with LD-SC (OZ/LD rats)

The immunohistochemical determination of Oil red $\mathrm{O}$, a fat stain, shows that there is a nonsignificant trend of fat infiltration in the corpora cavernosa of the OZ/UT versus the LZ/UT that is normalized in the OZ/ED (Fig. 4). In contrast, the OZ/LD is significantly richer in fat than the LZ/UT. This shows a definite effect of LD-SC in promoting a potentially deleterious corporal fat infiltration

\section{The LD-SC, but not the ED-SC, failed to increase corporal nNOS and increased myostatin, when injected into the corpora cavernosa of late diabetes $\mathrm{OZ}$ rats}

Western blot analysis in Fig. 5 top shows that nNOS levels, a protein marker of nitrergic neurotransmission in the penile nerve terminals and initiator of erectile function, are not significantly decreased by prolonged exposure to T2D in the OZ/UT versus the LZ/UT rats, and are increased in the OZ/ED rats although not in the OZ/LD rats. A similar lack of effects of T2D on the OZ/UT rats, as compared with the LZ/UT rats, was observed on eNOS, the endothelial protein marker partially responsible for the maintenance of corporal relaxation (bottom). In this case, the three OZ treated groups had higher eNOS levels than the untreated OZ rats. Therefore, the ability of ED-SC to stimulate the expression of nNOS was lost in their LD-SC counterparts, resembling their respective effects on SMC content, but this impairment did not affect their stimulation of eNOS content.

\section{DISCUSSION}

The observed MDSC transcriptional alterations suggest an inflammatory/fibrotic/ chemokine-enriched phenotype of the stem cells exposed to T2D for a long period in the 
donor tissue of origin. The altered transcriptional expression of certain key genes in the LDSC may be a main factor for their impaired ability to repair corporal tissue damage when implanted allogenically into the corpora cavernosa of the frankly diabetic 9 month-old OZ rats. This may be compounded by the upregulation of myostatin, a muscle mass inhibitor and pro-fibrotic factor, that is induced by the implantation of the stem cells themselves, specifically the LD-SC, similarly to what we observed in the corporal smooth muscle of rats with CVOD caused by cavernosal nerve damage treated with either MDSC or iPS $(40,47$ ), and in the skeletal muscle of T2D mice with critical limb ischemia treated with MDSC $\left({ }^{48}\right)$.

The report of stem cells treatment of erectile dysfunction in a claimed T2D model $\left({ }^{24}\right)$ was conducted on a non-genetically diabetic Sprague Dawley rat. The high fat diet feeding may have been insufficient to elicit diabetes since streptozotocin was injected after 28 days thus confusing the pathophysiology of the hyperglycemia, and obesity was not reported. In the other report, there is uncertainty regarding the origin of the corporal tissue damage underlying the reported erectile dysfunction that was treated by the adipose-derived stem cells $(25)$, since in this strain we have found normal erectile response to EFS even in a much higher hyperglycemia $\left({ }^{41}\right)$. Therefore, we believe that the current work is the first to demonstrate the efficacy of stem cells to ameliorate erectile dysfunction, in this case CVOD, in an accepted T2D animal model. Both CVOD and the underlying corporal histopathology in the OZ-UT are moderate and much milder in comparison to the LZ-UT than the alterations seen in TD1 models like the streptozotocin rat. This supports the view that the $\mathrm{OZ}$ rats represent better the slow progression with age and diabetes exposure of erectile dysfunction occurring in human diabetes, instead of the severe fast changes seen in other T1D and T2D models, and still defines the corporal tissue repair ability of MDSC and its impairment by their long exposure to the T2D milieu.

We consider that the ED-SC are the adequate control for the LD-ES since both stem cells are obtained from the same rat strain with identical genetic background, differing only on the length and intensity of MDSC exposure to the T2D milieu, which is virtually nil in ED-SC but very considerable in LD-SC. As opposed to pharmacologically induced diabetes, controls for genetic models can only be those at early stages in diabetes manifestation and progression. The use of controls such as MDSC isolated from LZ rats (a related but different strain), would have complicated the desired comparison and its extrapolation to humans, since it would not represent the effect of T2D on autografts from the same patient. Unresolved issues such as whether the stimulation of nNOS levels by the ED-SC is due to a neurotrophic or a differentiation effect, or whether eNOS upregulation by all the MDSC types occurs by affecting endothelium content, are not crucial for the aim of this study and requires further future work.

Our most significant finding is the noxious impact of long-term T2D on the transcriptional signature of the MDSC and their ability to repair the corporal tissue, evidenced in the LDSC exposed for 4-5 months to moderate hyperglycemia and severe dyslipidemia, As to the biological implications, there is increasing interest on the impact of normal aging in inducing senescence on stem cells $\left({ }^{42}\right)$, but it is less clear in the case of diabetes where causes may be more multifactorial and the damage may be more complex than that operating in aging $\left({ }^{43}\right)$. This MDSC impairment may resemble the one caused in differentiated cells 
that is intended to be counteracted by the injected stem cells. The T2DM impact occurred on two locations and cell types: the MDSC in the skeletal muscle niche impairing their repair capacity, and the SMC in the penile corpora cavernosa niche, leading to their loss or dysfunction and causing CVOD.

Very little is known on whether, and how, long-term exposure to uncontrolled diabetes may affect stem cells. Some studies emphasize the effect of hyperglycemia $\left({ }^{44}\right)$, reactive oxygen species, specifically $\mathrm{H} 2 \mathrm{O} 2$, and oxidative stress on mitochondrial respiration and apoptosis, mainly in endothelial progenitor cells, which in fact are not so obvious in the transcriptional signature of our LD-SC. However, other T2D milieu factors, such as saturated fatty acids and pro-inflammatory eicosanoids are also postulated to impair stem cells $\left({ }^{45}\right)$.

Our previous study had shown that CVOD could be detected as early as 7 months of age in OZ rats with a glycemia of only about $200 \mathrm{mg} / \mathrm{dl}$ but with morbid obesity and dyslipidemia, but not at the same age in ZDF rats with over $500 \mathrm{mg} / \mathrm{dl}$ glycemia and only mild overweight and lower dyslipidemia than in the $\mathrm{OZ}$ rats $(20,41)$. Therefore, we postulated that the dyslipidemia, probably in concert with hyperglycemia, and not hyperglycemia alone, was the main factor in causing corporal SMC loss, fibrosis and fat infiltration, and therefore CVOD. With the same reasoning we are now assuming that long-term exposure of MDSC in the skeletal muscle niche to this strongly dyslipidemic albeit moderately hyperglycemic milieu (but not to the ZDF hyperglycemic alone milieu), is probably the trigger for the transcriptional signature changes and loss of repair capacity observed in LD-SC.

The fact that in vitro incubation of normal ED-SC to culture medium with $25 \mathrm{mM}$ glucose did not impair their repair ability in vivo seems to support our assumption, although the in vitro exposure time may have been too short. Finally, the overproduction by the implanted LP-SC, but not by ED-SC, of myostatin may contribute to the impairment of their tissue repair capacity by counteracting their beneficial effects on the host tissue, since myostatin is a muscle mass inhibitor and lipofibrotic effector. The focus of this already extensive in vivo work did not allow to expand on mechanistic interpretations that are currently ongoing in a separate cell culture study.

\section{CONCLUSIONS}

Our study has shown for the first time that stem cells, in this case MDSC from an initially non-openly diabetic rat, were able to counteract erectile dysfunction, in this case CVOD, in a true T2D model, the 7-9 month old OZ male rat, and corrected its underlying corporal histopathology by increasing the SMC/collagen ratio and reducing collagen and fat content, while inducing higher nNOS and eNOS levels. This report is also the first to establish that a noxious tissue milieu affecting the skeletal muscle source of the MDSC, created by a longterm moderate hyperglycemia and a severe dyslipidemia, imprints the stem cells (MDSC) isolated from this tissue in the diabetic rats, the LD-SC, which lose their repair capacity. This was evidenced by some drastic changes in their global transcriptional signature, when compared with their ED-SC counterparts exposed short term to a more physiological milieu under a virtual normoglycemia, and only mild dyslipidemia. 
Our findings may have implications for the use of autologous MDSC from the patient with T2D, or stem cells from other tissues, for the therapy of erectile dysfunction or other disorders. The potential risk is that stem cells may be as affected by the T2D milieu as the damaged or lost differentiated cells they are intended to replace in the host T2D tissues. This would suggest that allergenic non-diabetic donors may be preferable despite potential immune rejection complications. The alternative is in vitro stemness reprogramming with small molecules that "rejuvenate" or "repair" the diabetic stem cells themselves $\left({ }^{46}\right)$, and to minimize the initial dyslipidemic stem and differentiated cell damage in vivo by combating morbid obesity/T2D.

\section{Acknowledgments}

This work was supported by a grant from the American Diabetes Association \#7-12-BS-062 to NGC, and in part by a grant from NIDDK DIACOMP Pilot and Feasibility Award to NGC

\section{Abbreviations}

CVOD corporal veno-occlusive dysfunction

ED-SC early diabetes stem cells isolated and cultured in low glucose medium

ED-HG-SC ED-SC incubated in vitro in high glucose conditions

eNOS endothelial nitric oxide synthase or eNOS 3

LD-SC late diabetes stem cells isolated and cultured in high glucose medium;

LZ lean non-diabetic Zucker rats

LZ/UT LZ, untreated

nNOS neuronal NOS or nNOS 1

MDSC muscle derived stem cells

$\mathrm{OZ}$ diabetic obese Zucker rats

OZ/ED $\mathrm{OZ}$ treated with ED-SC

OZ/ED-HG OZ treated with LD-HG-SC

OZ/LD OZ treated with LD-SC

OZ/UT OZ rats, untreated

SMC smooth muscle cells

\section{REFERENCES}

1. Malavige LS, Levy JC. Erectile dysfunction in diabetes mellitus. J Sex Med. 2009; 6:1232-1247. [PubMed: 19210706]

2. Hidalgo-Tamola J, Chitaley K. Review type 2 diabetes mellitus and erectile dysfunction. J Sex Med. 2009; 6:916-926. [PubMed: 19067787]

3. Miller DC, Saigal CS, Litwin MS. The demographic burden of urologic diseases in America. Urol Clin North Am. 2009; 36:11-27. [PubMed: 19038632] 
4. Martin AL, Huelin R, Wilson D, Foster TS, Mould JF. A systematic review assessing the economic impact of sildenafil citrate (Viagra) in the treatment of erectile dysfunction. J Sex Med. 2013; 10:1389-1400. [PubMed: 23347555]

5. Maseroli E, Corona G, Rastrelli G, Lotti F, Cipriani S, Forti G, Mannucci E, Maggi M. Prevalence of endocrine and metabolic disorders in subjects with erectile dysfunction: a comparative study. J Sex Med. 2015; 12:956-965. [PubMed: 25689116]

6. Sarwer DB, Spitzer JC, Wadden TA, Rosen RC, Mitchell JE, Lancaster K, Courcoulas A, Gourash W, Christian NJ. Sexual functioning and sex hormones in persons with extreme obesity and seeking surgical and nonsurgical weight loss. Surg Obes Relat Dis. 2013; 9:997-1007. [PubMed: 24120985]

7. Corona G, Rastrelli G, Filippi S, Vignozzi L, Mannucci E, Maggi M. Erectile dysfunction and central obesity: an Italian perspective. Asian J Androl. 2014; 16:581-591. [PubMed: 24713832]

8. Gandaglia G, Salonia A, Passoni N, Montorsi P, Briganti A, Montorsi F. Erectile dysfunction as a cardiovascular risk factor in patients with diabetes. Endocrine. 2013; 43:285-292. [PubMed: 22948773]

9. Miner MM, Kuritzky L. Erectile dysfunction: a sentinel marker for cardiovascular disease in primary care. Cleve Clin J Med. 2007; 74(Suppl 3):S30-S37. [PubMed: 17549823]

10. Condorelli RA, Calogero AE, Favilla V, Morgia G, Johnson EO, Castiglione R, Salemi M, Mongioí L, Nicoletti C, Duca Y, Di Mauro M, Vicari E, La Vignera S. Arterial erectile dysfunction: different severities of endothelial apoptosis between diabetic patients "responders" and "non responders" to sildenafil. Eur J Intern Med. 2013; 24:234-240. [PubMed: 23357410]

11. Blonde L. Sildenafil citrate for erectile dysfunction in men with diabetes and cardiovascular risk factors: a retrospective analysis of pooled data from placebo-controlled trials. Curr Med Res Opin. 2006; 22:2111-2120. [PubMed: 17076971]

12. Kirilmaz U, Guzel O, Aslan Y, Balci M, Tuncel A, Atan A. The effect of lifestyle modification and glycemic control on the efficiency of sildenafil citrate in patients with erectile dysfunction due to type-2 diabetes mellitus. Aging Male. 2015; 6:1-5.

13. Wessells H, Penson DF, Cleary P, Rutledge BN, Lachin JM, McVary KT, Schade DS, Sarma AV. Diabetes Control and Complications Trial/Epidemiology of Diabetes Interventions and Complications Research Group. Effect of intensive glycemic therapy on erectile function in men with type 1 diabetes. J Urol. 2011; 185:1828-1834. [PubMed: 21420129]

14. Awad H, Salem A, Gadalla A, El Wafa NA, Mohamed OA. Erectile function in men with diabetes type 2: correlation with glycemic control. Int J Impot Res. 2010; 22:36-9. [PubMed: 19759543]

15. Teloken PE, Park K, Parker M, Guhring P, Narus J, Mulhall JP. The false diagnosis of venous leak: prevalence and predictors. J Sex Med. 2011; 8:2344-2349. [PubMed: 21569215]

16. Deveci S, O'Brien K, Ahmed A, Parker M, Guhring P, Mulhall JP. Can the International Index of Erectile Function distinguish between organic and psychogenic erectile function? BJU Int. 2008; 102:354-356. [PubMed: 18336609]

17. Gonzalez-Cadavid NF. Mechanisms of penile fibrosis. J Sex Med. 2009; 6(Suppl 3):353-62. [PubMed: 19267860]

18. Lin CS, Xin Z, Dai J, Huang YC, Lue TF. Stem-cell therapy for erectile dysfunction. Expert Opin Biol Ther. 2013; 13:1585-1597. [PubMed: 24090162]

19. Gur S, Peak TC, Kadowitz PJ, Sikka SC, Hellstrom WJ. Review of erectile dysfunction in diabetic animal models. Curr Diabetes Rev. 2014; 10:61-73. [PubMed: 24295372]

20. Kovanecz I, Ferrini MG, Vernet D, Nolazco G, Rajfer J, Gonzalez-Cadavid NF. Pioglitazone prevents corporal veno-occlusive dysfunction in a rat model of type 2 diabetes mellitus. BJU Int. 2006; 98:116-124. [PubMed: 16831155]

21. Toblli JE, Ferrini MG, Cao G, Vernet D, Angerosa M, Gonzalez-Cadavid NF. Antifibrotic effects of pioglitazone on the kidney in a rat model of type 2 diabetes mellitus. Nephrol Dial Transpl. 2009; 24:2384-2391.

22. Toblli JE, Cao G, Giani JF, Angerosa M, Dominici FP, Gonzalez-Cadavid NF. Antifibrotic effects of pioglitazone at low doses on the diabetic rat kidney are associated with the improvement of markers of cell turnover, tubular and endothelial integrity, and angiogenesis. Kidney Blood Press Res. 2011; 34:20-33. [PubMed: 21071958] 
23. Kovanecz I, Nolazco G, Ferrini MG, Toblli JE, Heydarkhan S, Vernet D, Rajfer J, GonzalezCadavid NF. Early onset of fibrosis within the arterial media in a rat model of type 2 diabetes mellitus exhibiting erectile dysfunction. BJU Int. 2009; 103:1396-1404. [PubMed: 19154511]

24. Ouyang B, Sun X, Han D, Chen S, Yao B, Gao Y, Bian J, Huang Y, Zhang Y, Wan Z, Yang B, Xiao H, Songyang Z, Liu G, Zhang Y, Deng C. Human urine-derived stem cells alone or geneticallymodified with FGF2 Improve type 2 diabetic erectile dysfunction in a rat model. PLoS One. 2014; 9:e92825. [PubMed: 24663037]

25. Garcia MM, Fandel TM, Lin G, Shindel AW, Banie L, Lin CS, Lue TF. Treatment of erectile dysfunction in the obese type 2 diabetic ZDF rat with adipose tissue-derived stem cells. J Sex Med. 2010; 7:89-98. [PubMed: 20104670]

26. Bahk JY, Jung JH, Han H, Min SK, Lee YS. Treatment of diabetic impotence with umbilical cord blood stem cell intracavernosal transplant: preliminary report of 7 cases. Exp Clin Transplant. 2010; 8:150-160. [PubMed: 20565373]

27. Usas A, Huard J. Muscle-derived stem cells for tissue engineering and regenerative therapy. Biomaterials. 2007; 28:5401-5406. [PubMed: 17915311]

28. Relaix F, Marcelle C. Muscle stem cells. Curr Opin Cell Biol. 2009; 21:748-753. [PubMed: 19932015]

29. Tamaki T, Okada Y, Uchiyama Y, Tono K, Masuda M, Wada M, Hoshi A, Akatsuka A. Synchronized reconstitution of muscle fibers, peripheral nerves and blood vessels by murine skeletal muscle-derived CD34(-)/45 (-) cells. Histochem Cell Biol. 2007; 128:349-360. [PubMed: 17762938]

30. Arriero M, Brodsky SV, Gealekman O, Lucas PA, Goligorsky MS. Adult skeletal muscle stem cells differentiate into endothelial lineage and ameliorate renal dysfunction after acute ischemia. Am J Physiol Renal Physiol. 2004; 287:F621-F627. [PubMed: 15198930]

31. Kovanecz I, Rivera S, Nolazco G, Vernet D, Segura D, Gharib S, Rajfer J, Gonzalez-Cadavid NF. Separate or combined treatments with daily sildenafil, molsidomine, or muscle-derived stem cells prevent erectile dysfunction in a rat model of cavernosal nerve damage. J Sex Med. 2012; 9:28142826. [PubMed: 22974131]

32. Nolazco G, Kovanecz I, Vernet D, Gelfand RA, Tsao J, Ferrini MG, Magee T, Rajfer J, GonzalezCadavid NF. Effect of muscle-derived stem cells on the restoration of corpora cavernosa smooth muscle and erectile function in the aged rat. BJU Int. 2008; 101:1156-1164. [PubMed: 18294308]

33. Tsao J, Vernet DA, Gelfand R, Kovanecz I, Nolazco G, Bruhn KW, Gonzalez-Cadavid NF. Myostatin genetic inactivation inhibits myogenesis by muscle-derived stem cells in vitro but not when implanted in the mdx mouse muscle. Stem Cell Res Ther. 2013; 4:4. [PubMed: 23295128]

34. Wang JS, Kovanecz I, Vernet D, Nolazco G, Kopchok GE, Chow SL, White RA, GonzalezCadavid NF. Effects of sildenafil and/or muscle derived stem cells on myocardial infarction. J Transl Med. 2012; 10:159. [PubMed: 22871104]

35. Ho MH, Heydarkhan S, Vernet D, Kovanecz I, Ferrini MG, Bhatia NN, Gonzalez-Cadavid NF. Stimulating vaginal repair in rats through skeletal muscle-derived stem cells seeded on small intestinal submucosal scaffolds. Obstet Gynecol. 2009; 114:300-309. [PubMed: 19622991]

36. Kovanecz I, Gelfand R, Masouminia M, Gharib S, Segura D, Vernet D, Rajfer J, Li DK, Kannan K, Gonzalez-Cadavid NF. Oral Bisphenol A (BPA) given to rats at moderate doses is associated with erectile dysfunction, cavernosal lipofibrosis and alterations of global gene transcription. Int $\mathrm{J}$ Impot Res. 2014; 26:67-75. [PubMed: 24305612]

37. Ferrini MG, Rivera S, Moon J, Vernet D, Rajfer J, Gonzalez-Cadavid NF. The genetic inactivation of inducible nitric oxide synthase (iNOS) intensifies fibrosis and oxidative stress in the penile corpora cavernosa in type 1 diabetes. J Sex Med. 2010; 7:3033-3044. [PubMed: 20626593]

38. Gelfand RA, Vernet D, Kovanecz I, Rajfer J, Gonzalez-Cadavid NF. The transcriptional signatures of cells from the human Peyronie's disease plaque and the ability of these cells to generate a plaque in a rat model suggest potential therapeutic targets. J Sex Med. 2015; 12:313-327. [PubMed: 25496134]

39. Kovanecz I, Masouminia M, Gelfand R, Vernet D, Gonzalez-Cadavid NF. Myostatin is present in the perineal striated muscles and the penile corporal and arterial smooth muscle, suggesting a potential role in corporal fibrosis and penile growth. Int J Impot Res. 2015 submitted. Reported as: 
Kovanecz, I, Gelfand, R, Masouminia, M, Vernet, D, Rajfer, J, Gonzalez-Cadavid, NF. Myostatin, a key inhibitor of skeletal muscle mass and profibrotic factor, is expressed in the penile corporal and arterial smooth muscle, and may affect penile growth and smooth muscle content SMSNA Annual meeting, 2013, San Diego, CA.

40. Sakuma K, Aoi W, Yamaguchi A. The intriguing regulators of muscle mass in sarcopenia and muscular dystrophy. Front Aging Neurosci. 2014; 6:230. [PubMed: 25221510]

41. Kovanecz, I.; Nolazco, G.; Ferrini, MG.; Rivera, S.; Vernet, D.; Rajfer, J.; Gonzalez-Cadavid, NF. Severe hyperglycemia, renal damage, and low serum testosterone are insufficient in the absence of obesity to cause corporal veno-occlusive dysfunction (CVOD) in a rat model of type 2 diabetes. Am Urol Assoc Meet; Chicago, IL. 2009.

42. Sousa-Victor P, García-Prat L, Serrano AL, Perdiguero E, Muñoz-Cánoves P. Muscle stem cell aging: regulation and rejuvenation. Trends Endocrinol Metab. 2015; 26:287-296. [PubMed: 25869211]

43. Fujimiya M, Nagaishi K, Yamashita T, Ataka K. Bone marrow stem cell abnormality and diabetic complications. Anat Rec (Hoboken). 2012; 295:917-921. [PubMed: 22431187]

44. Petrelli A, Di Fenza R, Carvello M, Gatti F, Secchi A, Fiorina P. Strategies to reverse endothelial progenitor cell dysfunction in diabetes. Exp Diabetes Res. 2012; 2012:471823. [PubMed: 22474422]

45. Desouza CV. Does drug therapy reverse endothelial progenitor cell dysfunction in diabetes? J Diabetes Complications. 2013; 27:519-525. [PubMed: 23809765]

46. Avolio E, Gianfranceschi G, Cesselli D, Caragnano A, Athanasakis E, Katare R, Meloni M, Palma A, Barchiesi A, Vascotto C, Toffoletto B, Mazzega E, Finato N, Aresu G, Livi U, Emanueli C, Scoles G, Beltrami CA, Madeddu P, Beltrami AP. Ex vivo molecular rejuvenation improves the therapeutic activity of senescent human cardiac stem cells in a mouse model of myocardial infarction. Stem Cells. 2014; 32:2373-2385. [PubMed: 24801508]

47. Vernet, D.; Kovanecz, I.; Masouminia, M.; Loni, L.; Aboagye, J.; Rajfer, J.; Izpisua-Belmonte, JC.; Gonzalez-Cadavid, NF. Induced pluripotent stem cells (iPS) ameliorate corporal veno-occlusive dysfunction (CVOD) in a rat model of bilateral cavernosal nerve resection (BCNR), possibly through cross-talk with penile stem cells. SMSNA Meeting; Miami, Fl. 2014.

48. Tsao J, Kovanecz I, Awadalla N, Gelfand R, Sinha-Hickim I, White RA, Gonzalez-Cadavid NF. Muscle derived stem cells counteract fat infiltration and stimulate the early stages of myofiber repair in diabetic muscle ischemia, in a process associated with overexpression of myostatin. $\mathbf{J}$ Translat Med. 2015 submitted. Reported as: Tsao, J, Awadalla, N, Kovanecz, I, Gonzalez-Cadavid, NF. Muscle derived stem cells (mdsc) stimulate the early repair of ischemic muscle. Translational Science Meet 2014 (ACTS/AFMR) Washington DC. 


\section{TAKE HOME MESSAGE}

Prolonged exposure of muscle derived stem cells to a type 2 diabetic milieu in their tissue of origin imprints their gene transcriptional profile, impairing their repair capacity to ameliorate erectile dysfunction and the underlying corporal histopathology in a rat model 

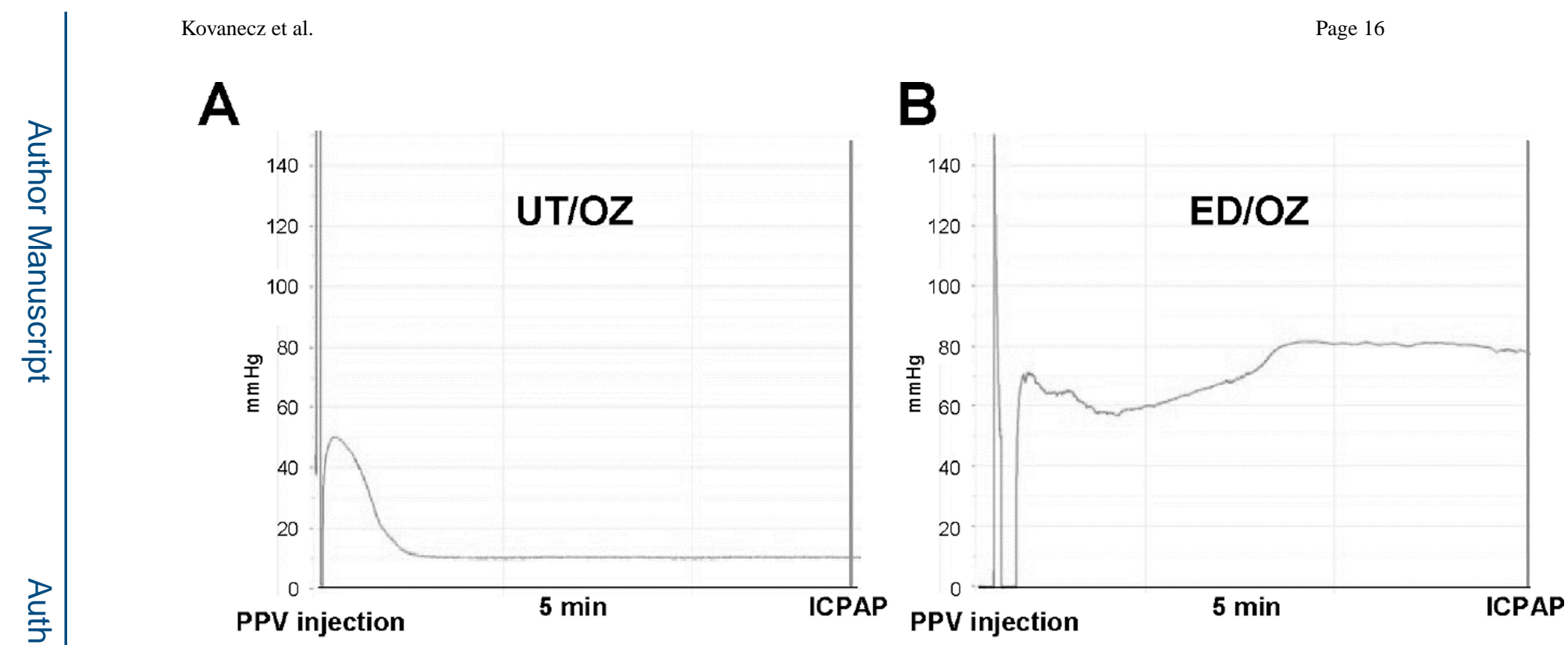

Q
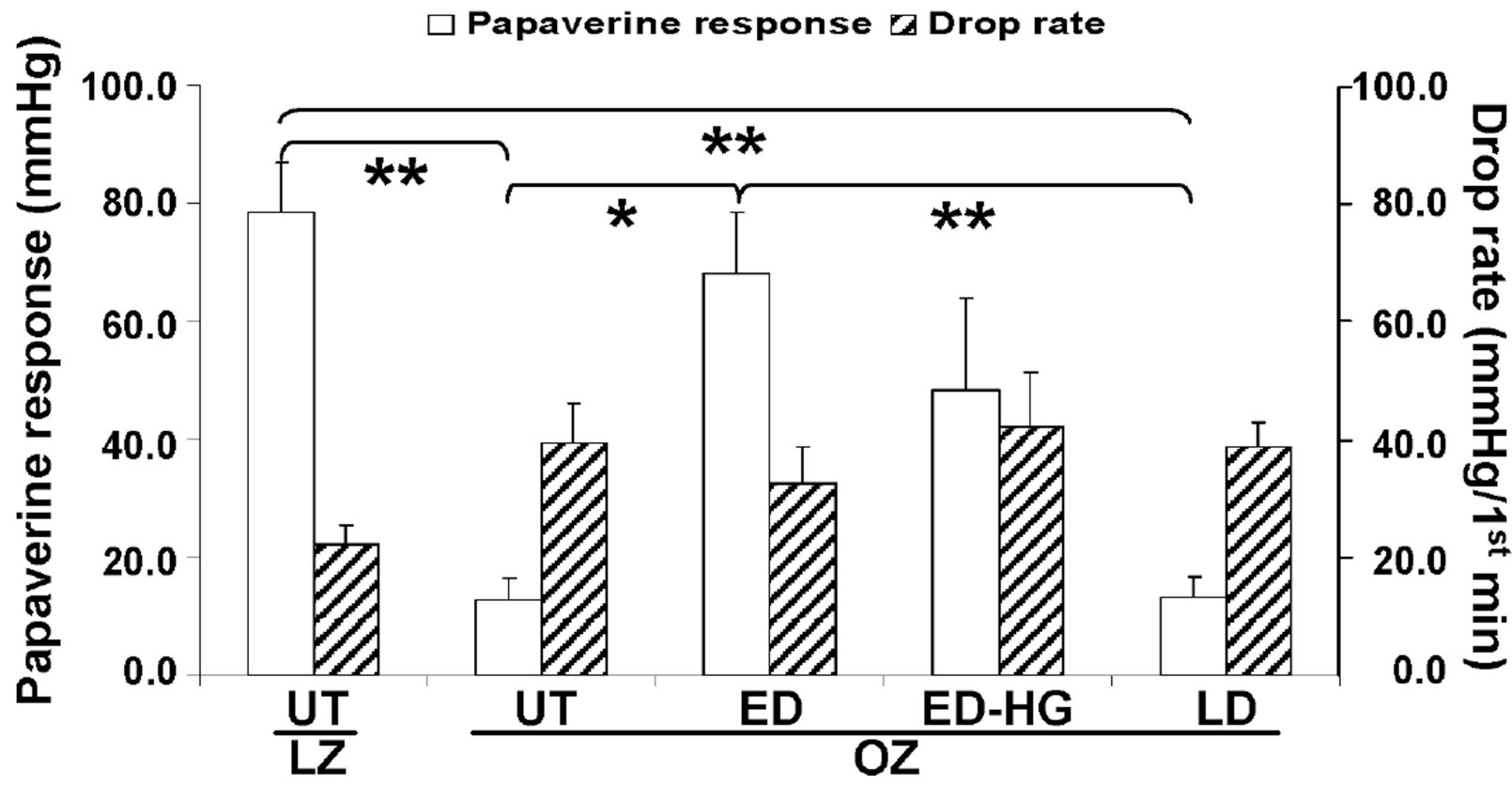

Figure 1. Stem cell treatment of long-term T2D rats improved CVOD, but only when the MDSC were obtained from the skeletal muscle of rats with early diabetes, and not from rats after longterm diabetes

Seven-month old rats ( $\mathrm{n}=8$ /group) were injected intracorporally twice with vehicle or MDSC over a 2 month course and subjected to cavernosometry. Top: Five minute recording of the response to papaverine (PPV) injection, as $\mathrm{mmHg}$ of intracavernosal pressure (ICPAP) in A) OZ/UT and B) OZ/ED. Bottom: C) Changes in intracorporal pressure. Left axis, clear columns: ICP 5 minutes after papaverine injection; Right axis, diagonal striped columns: drop rate; **: p<0.01; *: p<0.05; LZ/UT: lean Zucker non-diabetic rats, untreated; OZ/UT: obese Zucker diabetic rats, untreated; OZ/ED: obese Zucker diabetic rats, treated with early 
diabetes stem cells (ED-SC), isolated in low glucose (1\%) medium from the muscle of 3 month old OZ rats with very mild hyperglycemia/ dyslipidemia; OZ/ED-HG obese Zucker diabetic rats, treated with ED-SC that were previously incubated in vitro for 1 week under high glucose $(25 \mathrm{mM})$ in the medium (ED-HG-SC), to simulate hyperglycemia; OZ/LD obese Zucker diabetic rats, treated with late diabetes stem cells (LD-SC), isolated in high glucose (4\%) medium from the muscle of 7 month old OZ rats with very frank hyperglycemia and considerable dyslipidemia. 

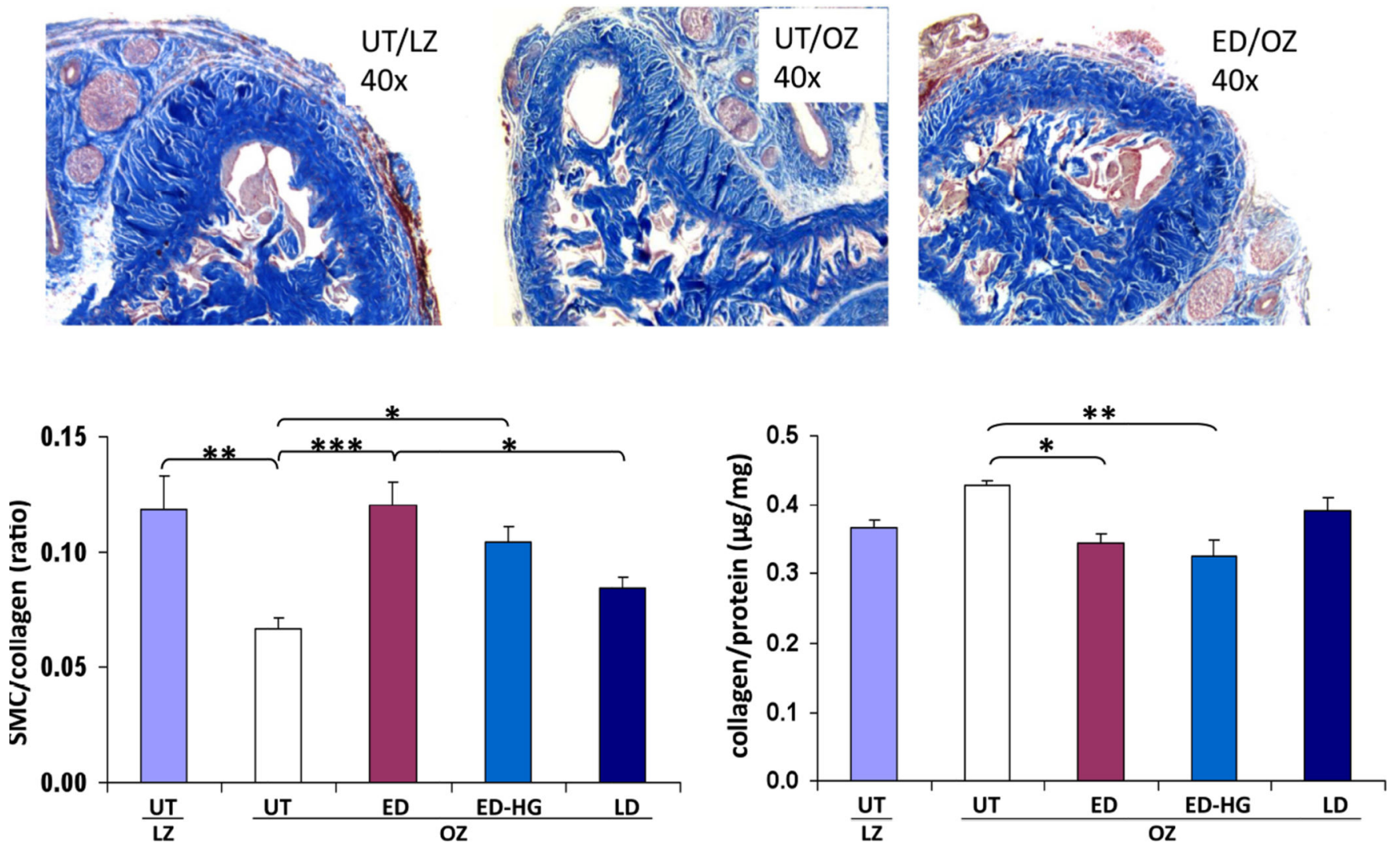

Figure 2. Intracorporally implanted MDSC isolated from the skeletal muscle of rats with early diabetes, but not from late diabetes, increased the corporal SMC/collagen ratio and decreased the denuded penile shaft collagen content

Top panel. Tissue sections from skin denuded penile shaft tissues were subjected to Masson trichrome staining and representative pictures are shown to compare the LZ-UT and OZ-UT with the OZ-ED rats (top). Differences are evaluated by measuring the SMC (red)/collagen (blue) area within the corpora cavernosa by quantitative image analysis. Bottom panel. Other frozen aliquots were used for collagen determinations using a hydroxyproline assay after protein hydrolysis. Abbreviations: see Fig. 1. ***: $p<0.001 ; * *: p<0.01 ; *: p<0.05$ 

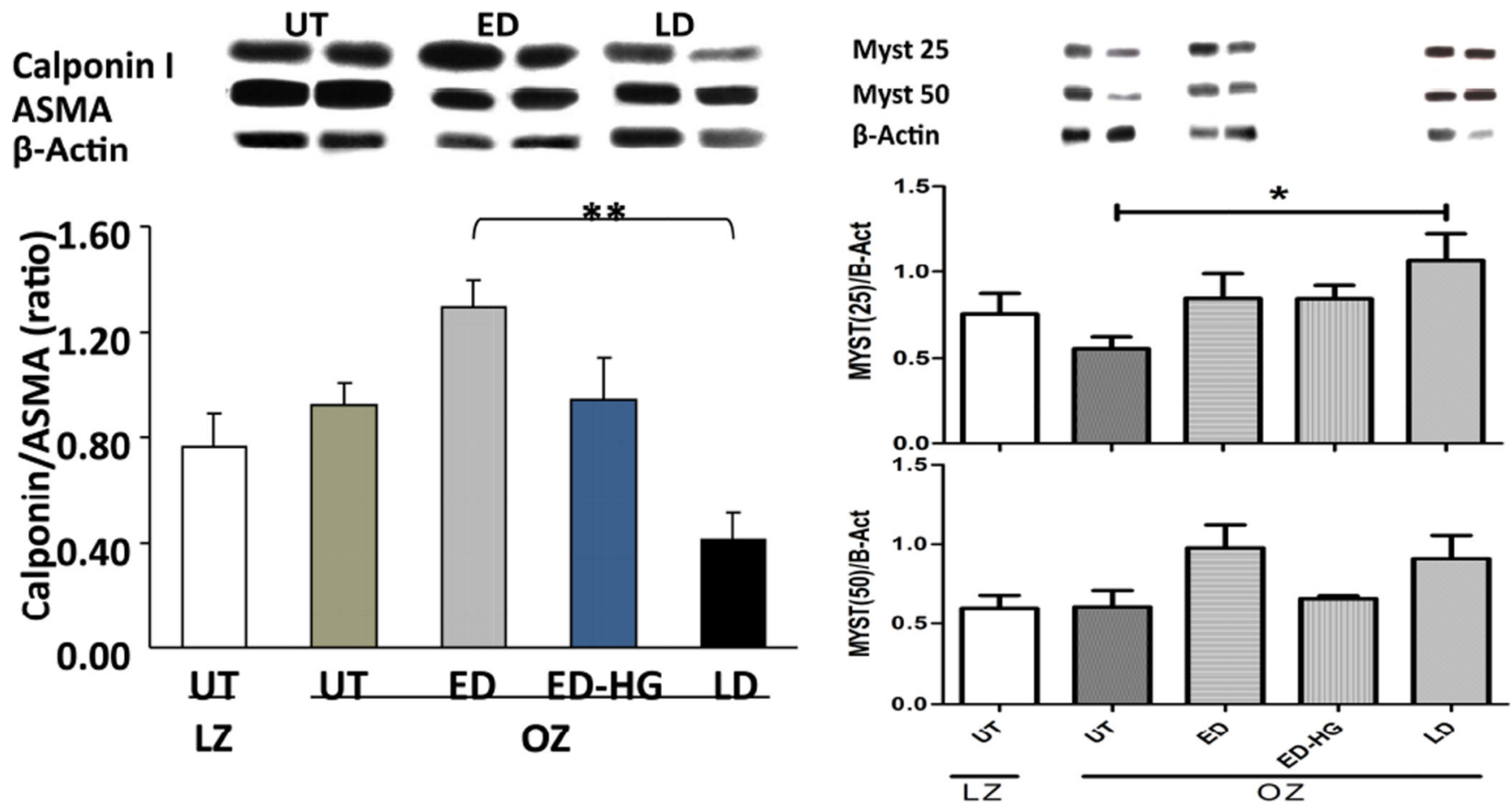

Figure 3. Intracorporally implanted MDSC isolated from the skeletal muscle of rats with early diabetes increased the denuded penile shaft smooth muscle content, whereas the late diabetes MDSC did not affect it and upregulated myostatin levels

Left panel. Frozen tissue aliquots were homogenized and subjected to quantitative western blot analysis for calponin 1 as a marker of SMC, and ASMA as a marker of both SMC and myofibroblasts. Representative pictures of the bands for calponin 1, ASMA and beta actin are presented (top), as well as the densitometric ratios between calponin and ASMA bands, corrected by beta actin as housekeeping gene (bottom). Right panel. Representative pictures of the bands for myostatin as inhibitor of muscle mass and lipofibrotic effector, and beta actin. The $25 \mathrm{kDa}$ band represents the cleaved active myostatin protein, assumed to be as a dimer and the $50 \mathrm{kDa}$ band correspond to unprocessed myostatin monomer (top). as well as bars for the densitometric ratios between the myostatin bands and beta actin (bottom).

Abbreviations: see Fig. 1. *: p $<0.05$ 

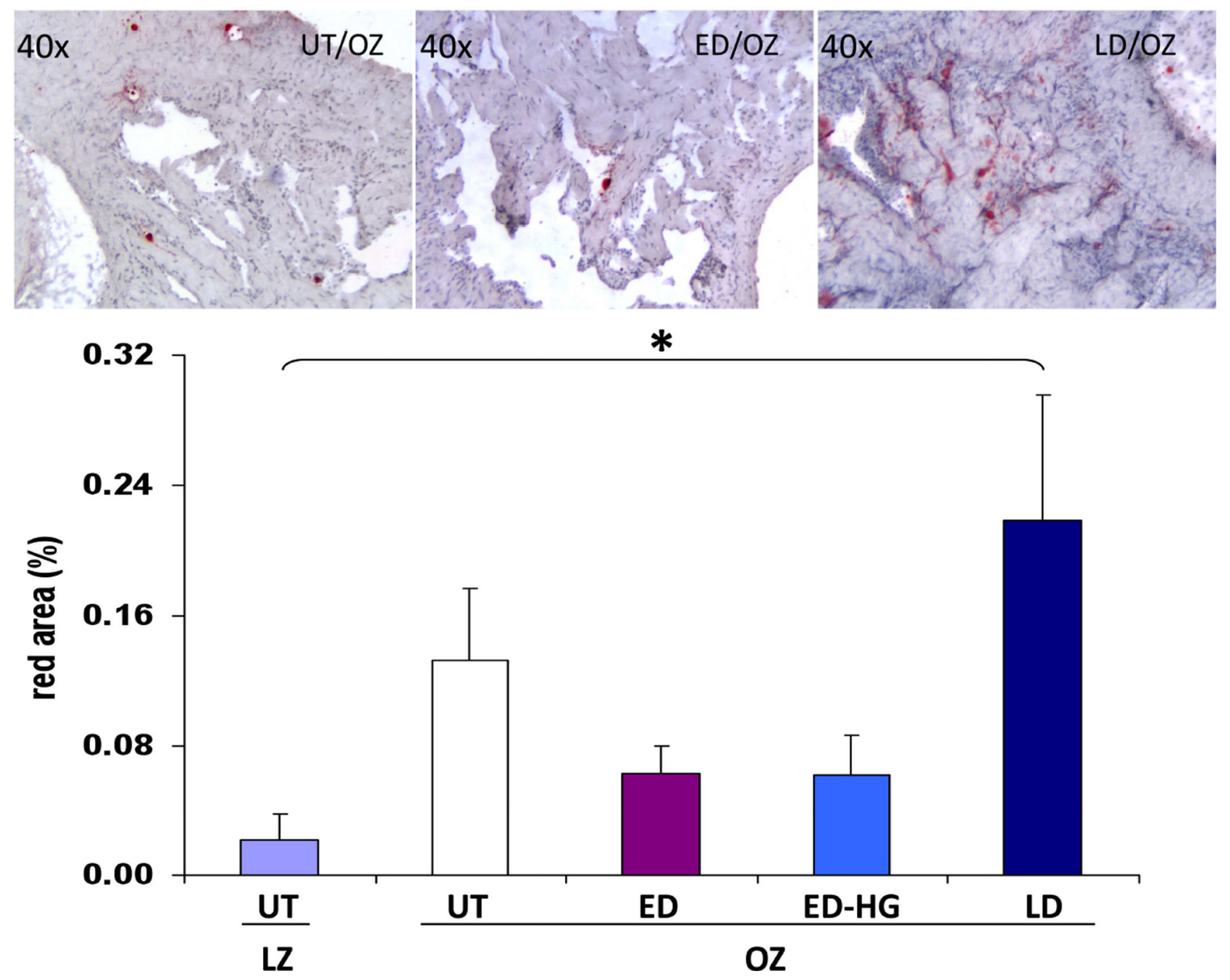

Figure 4. Intracorporally implanted MDSC isolated from the skeletal muscle of rats with early diabetes decreased fat infiltration in the corpora cavernosa, whereas the late diabetes MDSC increased it

Tissue sections from skin denuded penile shaft tissues were subjected to Oil Red O staining and representative pictures are shown to compare the LZ-UT and OZ-UT with the OZ-ED rats (top). Differences are evaluated by measuring the SMC (red)/collagen (blue) area within the corpora cavernosa by quantitative image analysis (bottom). Abbreviations: see Fig. 1. *: $\mathrm{p}<0.05$ 

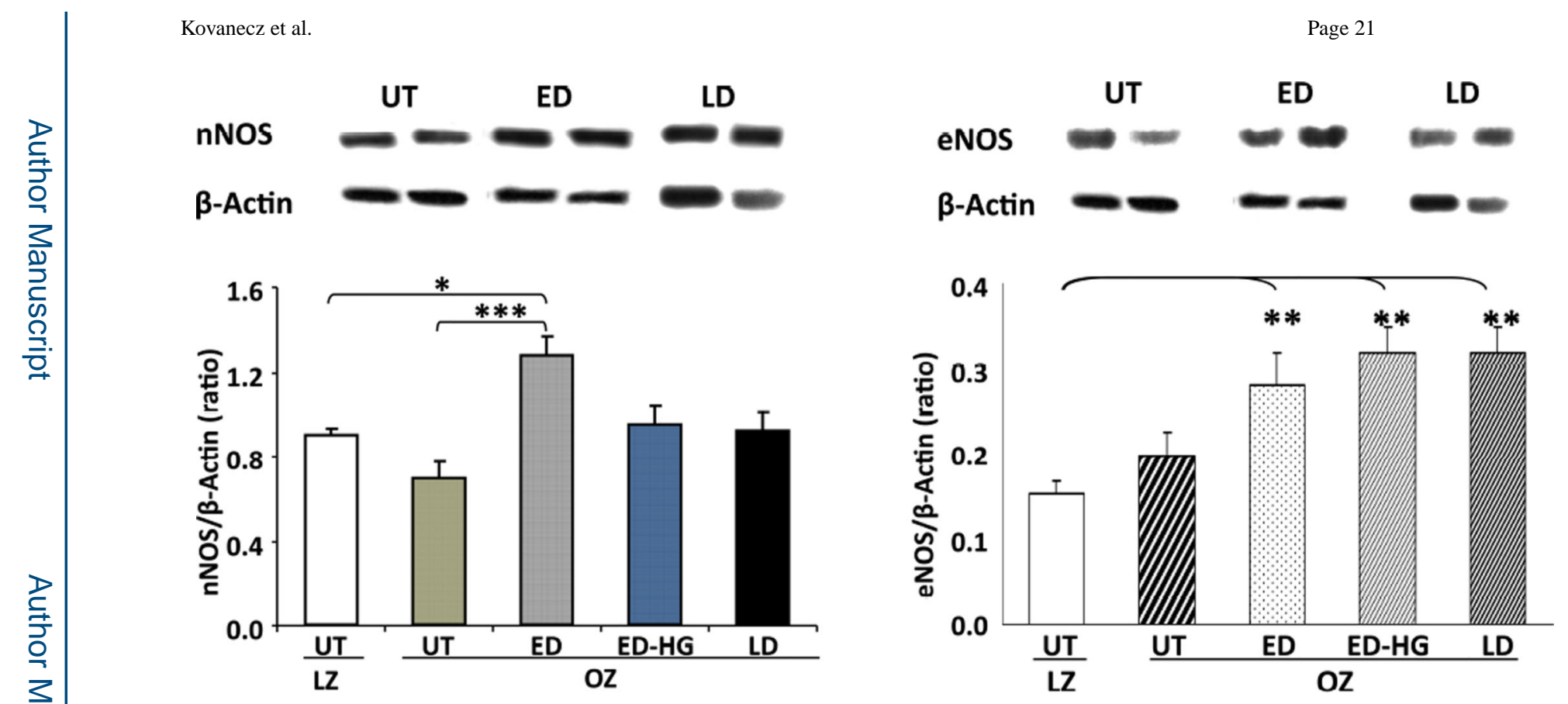

Figure 5. Intracorporally implanted MDSC isolated from the skeletal muscle of rats with early diabetes, increased nNOS and eNOS in the denuded penile shaft, but late diabetes stem cells failed to increase nNOS

Aliquots of tissue homogenates used for Fig. 3 were subjected to quantitative western blot analysis for nNOS (left panel) as a marker of nitrergic cavernosal nerve terminals and eNOS (right panel) as a marker of endothelium, Representative pictures of the bands for nNOS and beta actin, and eNOS and beta actin, are presented (top), as well as bars for the densitometric ratios for nNOS and eNOS, corrected by beta actin as housekeeping gene (bottom).

Abbreviations: see Fig. 1. ***: $\mathrm{p}<0.001 ; * *: \mathrm{p}<0.01 ; *: \mathrm{p}<0.05$ 


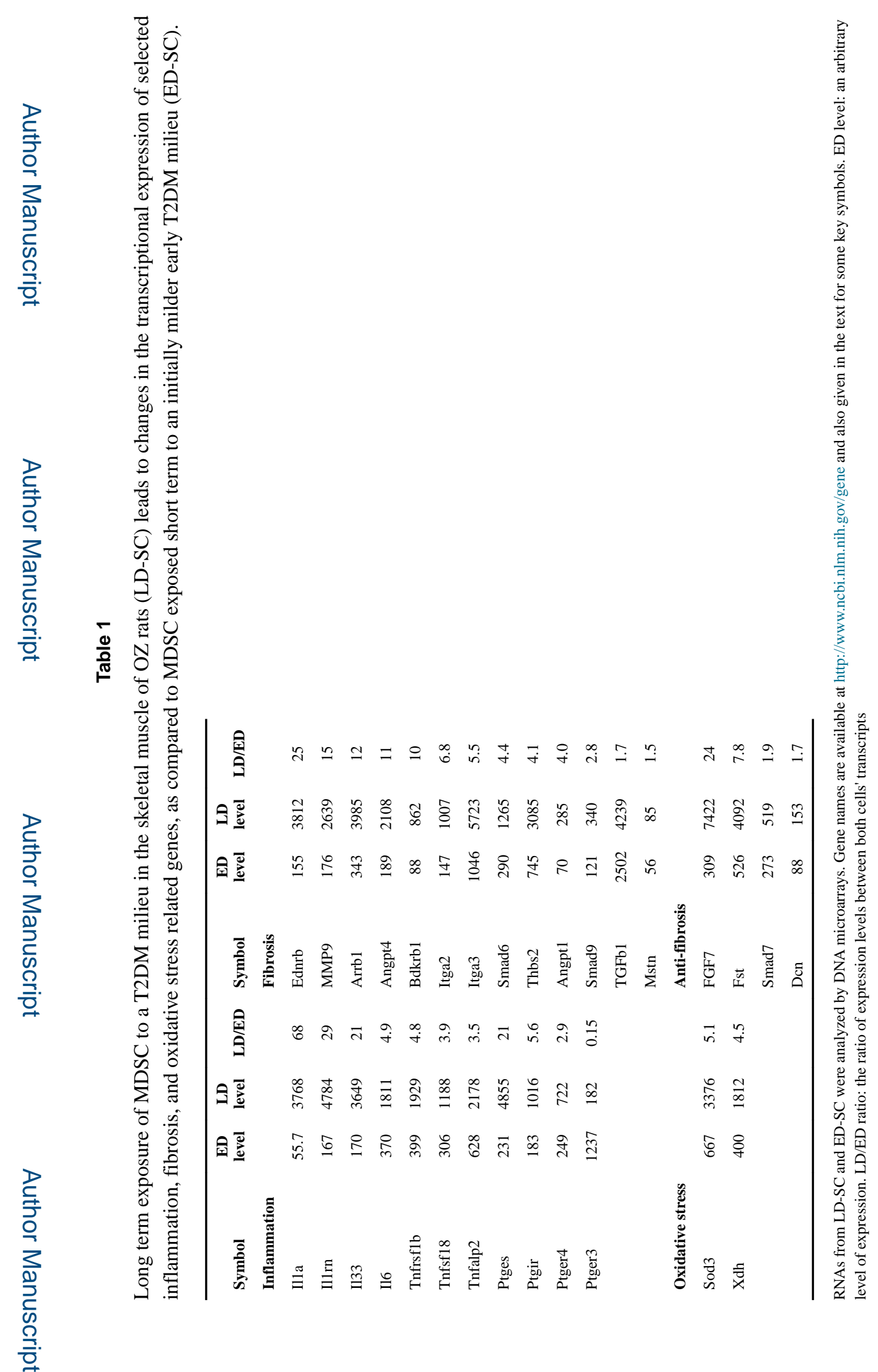

J Sex Med. Author manuscript; available in PMC 2017 May 01. 


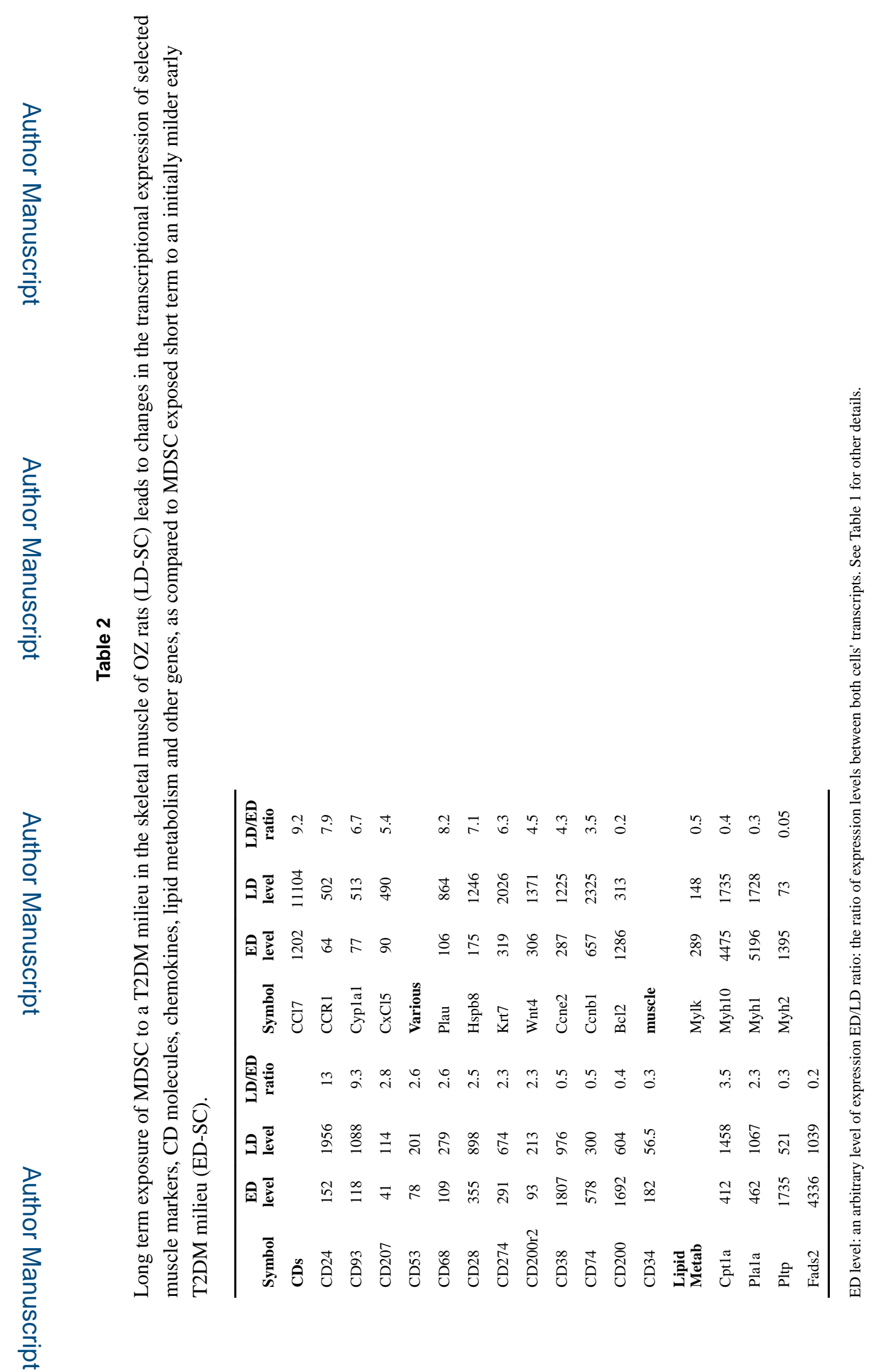

J Sex Med. Author manuscript; available in PMC 2017 May 01. 